\title{
ARTICLE
}

\section{Sports Law in Montenegro: Origins and Contemporary Development}

\author{
Marko Begović \\ University 'Union-Nikola Tesla', RS \\ marko.begovic@fzs.edu.rs
}

\begin{abstract}
This article represents a contribution to debates on national sport-related legislation, noting that academic engagement in the Balkan region has been silent on this matter. That said, the aim of this article is to present the historical developments of sports law in Montenegro, and to locate major developmental changes and dynamics within the contemporary setting. The end of the 19th and the beginning of the 20th century marked the first regulatory mechanisms for sports in Montenegro, adopting its organizational structure, internal regulations and procedures. The major changes occurred during the socialist period vis-à-vis organizational setting with the introduction of the delegate system with democratization and decentralization as the core principles. The decline of socialism has led to the dissolution of Yugoslavia resulting in the liberalization of the sports system dismantling the concept of physical culture. In contemporary developments, institutional setting and legal framework are more subject to political bargaining with strong state intervention and centralization in terms of policy planning and implementation.
\end{abstract}

Keywords: Montenegro; sports law; athletes; development; legal entities; sports history

\section{Introduction}

The expression 'State Law' was first used by Hegel, referring to his position that the state was the only source of legal power in a society (Đorđević 1975: 6). The state and legislation are complementary to one another, keeping in mind that both are the result of regulation of the social framework and constraints that follow. This further involves the application of the law through the behaviour of subjects following the norms and extraction of rights and obligations (Lukić 1957). The basic elements of the legislation are norms; grouped, they constitute the legal institute that regulates a particular social constellation, domain or activity. Such order further implies public jurisdiction for all parties under the competent authority, that is, with a recognized nexus, particularly through the convergence of the national legislation with provisions from international norms, customs and standards. As is vital for broader societal development, sports is subjected to a wide range of policymaking and planning in the community, such as health, social welfare, education, urban planning, conservation, arts and leisure. It plays an important role in the society contributing to cohesion processes (Bergsgard et al. 2007). Therefore, regulation of the sports, the role of the related public authorities and the position of sports stakeholders are crucial aspects to facilitate and to support the social function of sports. Of particular interest in exercising the full benefits of sports is regulating cooperation between public authorities and sports movement.

The level of involvement depends on the normative framework of the sports system in a given society. Andre-Noel Chaker's study (2004) shows that there is no unique approach regarding the legal position of the sports system at the Pan-EU level. Thus, the White Paper on sports acknowledges limits of EU cross-national legal limitations and attempts to act where necessary (sports as economic activity). Furthermore, it emphasizes the self-regulating principles and particular legal systems of the global sports movement that strengthen the autonomy of sports organizations through establishment of the globally harmonized lex sportiva. The nature of cooperation, jurisdiction and responsibility among stakeholders depends on the constitutional and legal system. That said, the aim of this article is to present the historical developments of sports law in Montenegro, and to locate major developmental changes and dynamics. As this work represents a pioneering venture, it will both contribute to the existing literature and represent a basis for more in-depth studies.

\section{Early Normative Arrangements}

In this section, I am going to briefly illuminate early normative arrangements that have resulted as a foundation for the contemporary development of sports law in Montenegro. General sociopolitical conditions for the development of organized sport were aggravated due to the continuous wars, the economic crisis, poverty and diseases (Radunović 
1980). The international recognition of Montenegro in 1878 sparked the legal foundation of organized physical activity and sport. Montenegrin scholar, Valtazar Bogišić, who was best known for his magnum opus 'The General Property Code for the Principality of Montenegro' proclaimed in 1888, that enacted the first provisions to regulate sporting activities such as horse racing, running, wrestling, shooting sports and archery and the game of chess (Art. 477) (Bogišić 1898). The major emphasis of this legislation was to place organized physical activity and sport as a part of the educational system and military readiness (Art. 102). The first sports rules were adopted as a 'Rules on gymnastics' foreseeing mandatory training, with structure and themes to be covered as a part of school curricula. The focus on gymnastics was not by accident. The strong influence of the Sokol movement, first founded in the Czech Republic in 1862, spread across the Balkans empowering emancipation processes and institutionalization of sport through adopting sport-specific rules and internal regulations. In a centralized manner, firstly the Ministry of Foreign Affairs and later the Ministry of Interior were in charge of developing the Sokol movement and granting permission to the Sokol clubs. The granting procedure presupposed a process of approving statute as a major internal regulation act. In 1912, the Ministry approved the first statute and internal regulations adopted by the Interim Committee of the Sokol club Dušan Silni.

As noted earlier, the first regulatory mechanisms for sports in Montenegro experienced in the late 19th century served as a source for early sport organizations-with the Sokol movement to adopt the organizational structure and implement sporting rules. These procedures presuppose that the Ministry of Interior approved the statute of an organization. One of the first statues was very comprehensive bearing in mind that it set out not only the clear membership procedure but its stipulated a check and balance mechanism based on the principles of depoliticization, transparency and accountability (Art. 3 and Art. 22). Also, rules for elections, desired profile, establishing of a quorum, extraordinary and emergency meetings, financial management, audit and disciplinary proceedings through the established Court of Honour (Art. 48). With the political implications of World War I (WWI), as a part of the Kingdom of Yugoslavia, the sport, however, enacted a more centralized and interventionist approach. The Law on Mandatory Physical Education adopted in 1932 stipulated strict rules on organizational setting and sports rules/programs for Sokol clubs and umbrella organizations with the Ministry for Physical Education acting in an executive manner (State Archive of Socialist Federal Republic of Yugoslavia [SFRY] 1932). The significance of these primordial rules laid the fundamentals for the legal regulation of sports. This constellation remained until the end of World War II (WWII).

\section{Development of Sports Law in Socialist Montenegro}

During the first years of the post-war period, the focus was on rebuilding the state's infrastructure, and sport had a semiregulated position. There were several commissions formed from 1947 until 1957 with no significant regulation with major jurisdictions transferred to organized sport. This legal framework resulted in the weak implementation of the strategy, and in 1957 the government adopted a decree to introduce a more interventionist approach with a special executive public body to oversee organized sport (Parliament of the Socialist Republic of Montenegro 1957). As Vujošević (1983) underlined, this solution proved to be ineffective, and the Executive Council of the Socialist Republic of Montenegro adopted a decree to establish the Republic Commission for Physical Education (preceding to ministerial level). The decree specified the tasks of the commission and organizational structure had foreseen an expert body in charge of developing further policies and regulations. The analysis of the 4-year strategic plan indicated still an ambiguous relation between the sports movement (sports organizations from the republic and local level) and competent public institutions. With this finding in mind and broader sociopolitical transformations, the Constitution from 1963 set up a foundation for more executive and interventionist regulation of sport that resulted in adopting a specific resolution on physical culture focusing on school sport organizations and recreational communities.

The political foundation for the development of the contemporary regulative policies was based on the Resolution of Physical Culture of the Federal Assembly of Yugoslavia from 1968. The legal grounds for regulating physical culture were laid down within the 1974 Constitution of socialist Yugoslavia. It recognized the citizens' rights to nurture and develop their persons, presupposing an increased need for play, recreation and other similar activities. Following broader sociopolitical transformation, the focus was on the decentralization of executive powers, that is, transferring jurisdiction and competences to the regional and local level, labour and youth organizations. As a constitutional category, physical culture was regulated by the Law on Physical Culture and Self-Management Communities of Interest (SIZs) (1976), Law on Associated Labour (1976) and the Resolution on the Yugoslav Assembly on the Free Exchange of Labour in Social Activities (1979). The Law on Physical Culture and SIZs from 1976 represented the continuation of the constitutional position of physical culture as an activity of public interest. Furthermore, in Article 3, physical culture was recognized as an inseparable human right. The law recognized SIZs, educational system, organizations of associated labour, organizations of physical culture (clubs), organizations of national defence and local communities/ districts as public authorities responsible for the development of physical culture. The focus has not been changed-it has remained on the development of school sports and recreational activities. Major changes, however, occurred in the organizational setting, introducing the delegate system. As the core principles were enacted-democratization and decentralization-the focus was to enable all stakeholders in organized sports equal access in the decision-making bodies and processes. To achieve this, the law recognized the Republic of Self-Managing Communities of Interest (RSIZ) and local self-managing communities of interest as the main public actors and the Republic Federation of Organizations for Physical Culture (RSOFK) as the main nongovernmental actor in the field of sports established with the self-management treaty to coordinate the implementation of public policies. 
Public policies were adopted by the RSIZ with broad sociopolitical consultation with workers' councils, youth organizations and the republic branches of the Communist Party of Yugoslvia KPJ. The local SIZ was established when the self-management agreement was accepted by the majority of workers and others from the associated labour organizations. The structure of the RSIZ was based on the principles from the Law on Associated Labour Labour (Radunović 1983). That said, the emphasis was on decentralization of decision-making processes that would affect and stimulate further democratization processes. In practice, athletes and other natural entities would be adequately represented in decision-making bodies. Furthermore, the main responsibility was to implement the programme based on the local, specific needs focusing on the development of mass sports movement and vocational training. Their law has undergone several minor changes with adopted amendments in 1979, 1982 and 1985. These amendments reflected the necessity to additionally strengthen self-management principles and SIZs as major sociopolitical organizations derived from those principles. Upon the new constitution and the Law on Republic Administration, the Commission received upgraded status (Parliament of the Socialist Republic of Montenegro 1965). This institutional setting remained until 1979 when the Executive Council placed physical culture under the Republic Commission of Education, Culture and Science. As noted earlier, the legal solution from the 1970s, focused dominantly on the school sport and recreational activities.

In respect to competitive sport, following the principle of amateurism, specific regulation was in place to regulate the status of athletes. At the central level, a Social Agreement on position, rewards and remuneration of top athletes was adopted by the Yugoslav Association for Physical Culture-Savez fizičke culture Jugoslavije (SFKJ, 1975). According to this regulation, there were three categories of athletes (merit, international and state class) with enacted provisions stipulating shared obligations for public authorities and sports movements. These obligations included a structured plan for medical care and insurance policy, social security, pension plan and remuneration. It underlined however the necessity for responsible authority to enable appropriate jobs taking into account the specificity of a particular sport.

\section{Contemporary Sports Law in Montenegro}

Legal continuity for sport remained as a constitutional provision in contemporary, sovereign Montenegro. In Article 77 of the Montenegrin Constitution, sport and physical culture are recognized in the 'Science, Culture and Art' section 'Montenegro is obliged to encourage and support education, science, culture, art, sport, physical and technical culture' (Parliament of Montenegro 2007). The rationale, sport available to everyone, behind the new Law on Sports is based on the following principles: (1) sport as an activity of public interest-fluid by nature, sport is seen as a tool and as an asset; (2) free accessibility of sport-the concept of the umbrella normative act for the field of sport is based on the free engagement in sport activities and equal access to these activities to all citizens without any discrimination; (3) freedom of association-as constitutional provisions related to the freedom of association, the private entrepreneurship and equality of all forms of ownership, it acknowledges a broad framework for free autonomy within its constituents; (4) athlete's health protection-legislation envisions obligatory medical control of athletes, prohibition of forcing athletes to train and compete and prohibition of using any kinds of doping or banned substances; (5) the principle of expertise/competence-professional work in sport and management of sport activities to be performed only under supervision by a qualified (trained) or professionally trained staff. The key legal basis for the planning and coordination of the public policies within the state administration is based on the Rules of Procedure of Government, Decree on Government, the Law on State Administration and the Law on Budget and Fiscal Responsibility (Government of Montenegro 2017c, 2018b, d). In addition, it defines the institutional mandate of the Government, its power to make decisions, relations with the Parliament and the mandate of state administration, where the distribution of responsibilities are stipulated with the Decree on organization and operation of the state authorities. Article 19 of the Decree stipulates that the Ministry for Sports and Youth (MSY) implements sports-related legislation and policy:

Adopting and monitoring the implementation of sport policy; determining policies in high-performance, recreational, kids, school and university sport; status, rights and obligations of athletes; the employment status of athletes and sport professional; sport activity of persons with disabilities; performing sporting activities by sport organizations and entrepreneurs; promotion and implementation of the National Plan; the establishment and operation of sport organizations; creation of conditions for the construction and maintenance of sport facilities; encouraging and monitoring the activities of the Montenegrin Olympic Committee (COK) and the National Sports Federations (NSF) (Government of Montenegro 2019a, b).

Furthermore, Article 19 of the Decree envisages, in terms of the hierarchy of public administration, that the MSY performs supervision of the legality of administrative acts and administrative procedures. The legal landmark of planning and operational activities in sports is based on the Law on Sports, the Law on Ratification of International Convention against Doping in Sports, the Law on Prevention of Spectator Violence and Misbehaviour at Sports Events, the Law on Public Ski Slopes, sports federation statutes, internal regulations, international- and national-based sports rules (COK, 47 National Sports Federations and all sports organizations) (Government of Montenegro 2008b; Government of Montenegro 2017a; Government of Montenegro 2017b; Government of Montenegro 2018c).

\section{Normative Arrangements for Natural Entities-Athletes}

Although the law recognizes an amateur athlete, professional athlete and recreational athlete, there is no clear distinction between an amateur and recreational athlete. An athlete may engage in sports activities independently or within 
an organization in the field of sports, either as an amateur or as a professional. Clear differentiation in terms of earnings/compensation between professional and amateur athletes is not in place, which functions as an aggravating factor in determining the status of a particular athlete. This is especially important for reasons of ensuring social, health and pension insurance, or insurance against injuries or accidents for athletes. It further understands the need for a clear distinction between transfer and assignment contracts of athletes followed by legally valid procedures based on the competition law and rules within a particular sport. Rights, obligations and responsibilities of professional athletes are partly regulated by the law, where responsibilities are transferred under the competent NSF. This arrangement presupposes a collective agreement or adoption of the appropriate rulebook with the employment contract between the athlete and sports organization in place. The provisions concerning contractual relations are, however, vague, although Petrić (2006) underlined that the rules on liability for legal and material defect fulfilment should apply to all parties within obligatory contract arrangements, which is recognized by Articles 2 to 11 and Article 20 of the Law of Obligations (Government of Montenegro 2008a). The Law on Sports stipulates and recognizes only professional athletes as entrepreneurs. This question seems to be overlooked, especially bearing in mind the importance of third parties (managers or intermediaries) in the field of professional sports and the overall impact on the economic safety of athletes.

A particularly sensitive issue is the transfer of minors: Article 17 of the Labour Law states that parental/guardian written consent is required and also obligating the sports organization to inform the responsible state authority, making sure to be in concert with the competent ISO, especially in the case of change of residence. Furthermore, not all rights and obligations of the parties that are defined by the aforementioned lex generalis were included in the provisions of the Law on Sports, which allows for interpretative freedom. This constellation has its repercussions on specific rights associated primarily with competitive sport: potential negative impacts on athletes, their rights and the overall image of sport. In particular, the prevention of negative phenomena in the transfer procedure of athletes whereby the majority of the transfer fees goes to third parties (i.e., managers), seems not to have received the needed attention. Moreover, the law does not stipulate that the contracts under which a third party acquires exclusive rights over economic rights, future transfers could be void/invalid. In the context of the need to protect athletes from any kind of exploitation, especially given that they are a vulnerable group, the law remains incomplete. With this in mind, any contractual provision between athlete and legal entity that is discriminatory should automatically be invalid, and allowing such practices would contravene constitutionally guaranteed rights. Termination of such a contract between an athlete and sports organization should not affect the sporting activities of an athlete and the right to participate in official competitions, where any violation could lead to litigation. Begović (2020) concluded that the inspection from 2013 and 2014 of NSF revealed that most of the professional contracts were bypassed by the scholarship contracts, with annexes or supplements of the contracts not accessible or had not been submitted legally.

To create a framework for an athlete's protection/recognition, iure imperii has been transferred to the COK to adopt and implement the bylaw on the categorization of sports and athletes. An athlete with extraordinary national team results is an athlete who, based on accomplished sports results, had a status of an athlete with the extraordinary national team or individual result (first, second and third place) in the Olympic Games, Paralympic Games, the only official world or European senior championship in a sports discipline that is featured in the programme of the Olympic Games or Paralympic Games (Art. 29). Also, boxers becoming world champion under the organization of World Boxing Council (WBC), World Boxing Association (WBA), World Boxing Organization (WBO) or International Boxing Federation (IBF) and tennis players becoming finalists under the organization of International Tennis Federation (ITF-Davis/FED cup) or Association of Tennis Professionals (ATP)/Women's Tennis Association (WTA) (Grand Slams) are recognized as attaining extraordinary results. Those athletes, meritorious sports professionals (top athletes), are entitled to a lifetime monthly compensation, and the right to a bonus for top sports results achieved. It implies the right for recompenses (compensation), following the prescribed criteria. Another category of the athlete is a promising athlete, who acquired a status of a promising athlete based on his accomplished sport second or third place in the official world or European championship for youth categories in a result (Art. 30). An athlete has the status of a promising athlete if first they compete in, a sport that is featured on the programme of OG (Olympic Games) or PG (Paralympic Games) or in a sport that is categorized as a category of sports that are not on the programme of the Olympic Games but are recognized by International Olympic Committee (IOC) (para 2). Regarding coaches, the law envisaged provision for the captain (coach) of the First National team of Montenegro (provided they are Montenegrin citizens) entitled to a bonus for top sport results accomplished. The athletes can obtain the right to receive payment of lifetime monthly compensation by the age of 35 years. The criteria for determining the amount of compensation or premium is determined by government decree (Government of Montenegro 2018a). The adopted decree prescribes the compensation amount and premiums for achieving sporting results. Although a distinction is made according to the placement in the official ranking system which recognizes the national team coach as well, the legislator does not make any differentiation between the status of athletes (amateur vs professional).

\section{Normative Arrangements for Legal Entities}

The Law defines a sports organization as a legal entity, along with its status, internal regulations, organizational character, establishment and termination procedures and protocols. The process of establishment requires the founder(s) to submit the founding act and appropriate statute, as well as evidence of the fulfilment of the conditions necessary for the operation of an organization. This includes the registration procedure, record-keeping methods and ex-officio 
removal from the Register of Sports Organizations by the MYS. The law does not recognize all existing forms of organization in the field of sports (such as professional sports clubs), the nature of activities and territorial affiliation, such as, unions of athletes, sports professionals, delegates or entourage. Some organizational forms are fully regulated, and some only in areas that are specific to the field of sports, whereas other aspects still require formulation. This is especially important since there is a significant number of non-government organizations (NGOs) in the field of sport registered with the Ministry of Public Administration. It is, therefore, impossible to determine the scope of competencies of those. In this area, the general conditions that need to be met by sports organizations are defined and regulated so they may perform sports activities. Specifically, each sports organization must adopt, state or prepare the following:

- Founding act

- Statute

- Affiliated or contracts of involved athletes

- Number of athletes involved, depending on the type of activity

- Provide adequate space, sports facilities and sports equipment

- An adequate internal organization and financial resources for taking part in sports competitions

- Contractually hired expert human resources and persons for carrying out expert work in sports

- Ensure the safety of athletes and other participants in the performance of sports activities.

As stipulated by the legislator, the founding act contains numerus clausus or inventory issues, with which an applicant is obliged to comply. As in the previous case but with a more general nature, the legislator stipulates numerus clausus, based on which the competent state authority imparts permit/consent. Except for the Founding Act, the statute also serves as a legal institute based on which competent state authority acts prima facie, assessing whether the sports principles/activities of public interest have been met. Although it is not explicit, ratio legis presupposes that statute will determine the various responsibilities of persons in the organizational structure, where acquired rights are not inherited nor can be transferred to third parties. On the contrary, because the law does not comply with the provisions from the EU Service Directive (that aims to remove barriers to enhance rights, fostering cooperation and simplifying administrative procedures), this calls into question the provision's constitutionality given Art. 9 of the Constitutioninternational treaties and accepted rules of international law have juridical power (supremacy) over national legislation (Directive 2006/123/EC). The law recognizes only not-for-profit organizations as legal entities involved in the sports system. This, sui generis solution, does not comply with the provisions enacted in the Law on NGOs, directing that any commercial/professional activity shall be registered under the Law on Business Organizations (Government of Montenegro 2012; Government of Montenegro 2008).

In most cases, NSF represents an International Sports Federation (ISF) and a particular sport in its country of origin. According to Begović (2020), NSF stands as a major player to implement sports policy under the legal framework. For a given sport, NSF acts as a supreme/umbrella organization establishing the rules and regulations within a particular sport. The NSF (1) coordinates the activities of its members; (2) determines and organizes the competition system; (3) registers and keeps records of members, athletes and other sports professionals, conducts contract depositing; (4) improves professional work and training of professionals, categorized and professional athletes; (5) cooperates with authorities, organizations and institution (Art. 41). It is bound to a specific sport that has jurisdiction over implementing sports rules, following international rules and standards of a specific sport. NSF is obliged to issue the following rulebooks: (1) on the organization of sports competitions; (2) on athletes' transfers; (3) on the fight against doping; (4) on licensing coaches; (5) on licensing referees and delegates; (6) on the admission of the sports organizations; (7) on measures to ensure the safety of participants in sports competitions (Art. 42).

\section{Results}

The decline of socialism has led to the dissolution of Yugoslavia with negative effects on sports (Begović 2020). The concept of physical culture has been dismantled. In 1994, the newly formed Ministry of Sports proposed the Law on Sports. The adopted legislation remained on the principle that sport is an activity of public interest. The major change, however, reflected broader political transformation, foreseeing the necessity of transformation of organizations of physical culture (clubs)-from social ownership to the private ones (OECD 2003). The process of privatization started with the introduction of the Property and Management Transformation Law transforming socially owned entities into public limited companies. Further economic liberalization continued with the adoption of the Law on Privatization in 1996 (and amendments from 2004) and resulted in massive privatization. Within the new sociopolitical reality, in 1998 sports organizations were transformed into private entities under the Decision on the Separate Transformation and Privatization Plan for Sports. Secondly, the Ministry of Sports was now in charge of control of enforcement provisions and inspection.

Due to the frequent institutional changes, the Law on Sports adopted in 2004 (with amendments from 2007) was founded on the concept of further liberalization of sports under the necessity to introduce the concept of the autonomy of sports movement. For the expertise, development of policies and advisory, the law envisaged the Sports Councilfounded directly by a decision of the Government of Montenegro. Secondly, the registration procedure went from the NGO status enacted by the Law on Association from 1971 to the registration as a sports organization within the Ministry 
of Education and Sports where sports organizations received a sui generis status-being recognized neither as NGOs nor as public institutions. A third important change was recognition of the status of the Top Athlete. According to Article 50 of the law, the status meant that the Top Athlete is entitled to lifetime compensation by the criteria enacted in the bylaw. Fourthly, the control earlier under the Ministries Commission was transferred to the competent public authority in charge of the inspection. As Begović et al. (2020) found, the institutional position of the sport was more subject to political bargaining and the sport was fluctuated from the Ministry of Culture and Sports, Ministry of Education and Sports, Directorate for Youth and Sports, recently receiving ministerial status in 2016 as Ministry of Sports and Youth. As a part of the Ministry of Education and Sports, the Law on Sports from 2011 included a provision for team coaches (captains) of the national team of Montenegro to receive a lifetime compensation under the same rules as a top athlete. Concerning the status of athletes, the categorization of athletes was enacted as an attempt to revive provisions from the 1970s. According to the Law on Arbitration and following international standards in dispute resolution mechanisms, the COK is required to establish the Court of Arbitration acting as a final instance, when needed. In addition, a particular NSF may transfer authority to the COK to settle sports disputes.

The recent Law on Sports (as of 2018) did introduce several changes that will impact the contemporary development of the sport. In respect to the status of athletes, a promising or talented athlete is recognized within the new law. Significant changes occur in the administrative aspect-the enacted provisions envision broader responsibilities and provisions for legal entities: (1) a legal entity must have a headquarters, (2) a secretary of the organization with an acquired sports exam-the ministry adopted a bylaw with a programme for a sports exam, (3) terms of reference for a general assembly, (4) a president of the organization, (5) a president of the general assembly and (6) board for the organization. Secondly, to protect the health of athletes, the government will establish the Agency for the health protection of athletes. According to Chaker's configuration, Begović (2020) concluded that Montenegro's sports system is interventionist-structures/roles/ responsibilities of the constituents of the sports movement are regulated within the law on sports along with appropriate bylaws; centralized-key legal bases for the planning and coordinating public policies in the state administration are centralized in the competent state authority with responsibilities to determine the scope, competencies and jurisdiction for all constituents of the sports movement; consolidated-the COK is recognized as the umbrella association of Olympic and non-Olympic sports and the POK as the umbrella association for Paralympic sports (Art. 45-46).

\section{Concluding remarks}

Through a normative lens, the challenge lies in resolving two contrary tendencies: (1) to strengthen relationships already built as a coherent whole, contributing to greater respect for the principle of legal certainty but at the same time not closing the way for the further evolution of civil rights; (2) the continuous improvement of the legal order as a whole. With this in mind, the core principles of understanding the legal nature of the sports movement and its constituents, along with lex generalis that enables the fundamental nature of nonprofit and nongovernmental associations, were neglected. The involvement of the public authorities is necessary from the regulatory point of view to serve the public interest by providing equal opportunities for exercising positive benefits from sports. Public authorities on all levels are responsible, either directly or by training others to improve access to sports and sports facilities to all people, regardless of their social origin, economic status, income, age, gender or ethnic affiliation. Sports should not be a sui generis activity-an exclusive right of protected categories of people. Public authorities are obliged to adopt strategic documents and operational plans for implementation of all activities of public interest encouraging mass participation and mass use of sports facilities with special attention to children, youths and athletes. In its general overview, an analysis of the Montenegrin legal framework could be said to contain these elements:

- certain provisions of the Law on Sports are unconstitutional-these refer primarily to the status of the sports organizations and the registration procedure

- inability to facilitate/provide equal opportunities for all-noncompetitive sports is largely disregarded

- inapplicability and inaccuracies of certain provisions-concerning the registration procedures and status of the natural entities

- noncompliance with enforced internationally binding norms-such as the fight against doping

- unregulated position of constituents/subjects of sports system along with clearly specified Terms of Reference (ToR)

- incompatible system of financial assistance for the activities of public interest through sports

- poor representation of athletes and other natural entities in policy planning and decision-making processes

- an inadequate health protection system

- absence of the dual-career system

- economic rights (contractual relations and transfers with special focus on minors)

- implementation of categorization of sports and athletes

- absence of the principle of equality of arms in dispute and arbitration proceedings.

The law does not stipulate the prohibition of any discrimination of athletes and sports professionals, and is conspicuous in restricting the rights of athletes in the decision-making process and transfer procedures. Furthermore, the lack 
of contractual obligations and the existence of classified contractual obligations (most of the contracts are composed jointly) has led to avoiding liability to register contracts between athletes and sports organizations and responsibilities under the financial and business legislation. The uncontrolled outflow of young athletes abroad is of great concern for competitive sports. Therefore, it is important to determine appropriate transfer/migration policies that would be in minors' best interest. Although the law properly encourages and facilitates means to resolve disputes in sports via arbitration or a disciplinary board (keeping comparative legislation in mind), significant irregularities can be noted in the constitution and operation of the permanent bodies within the sports movement in Montenegro, resulting in discouragement of sports subjects to fully exercise their rights.

In organizational terms, the legislator recognizes the NSF as an umbrella organization in the pyramidal structure of clubs and municipal associations, in charge of running all activities in a specific sport. Although it is properly stipulated that for one sport there can be one appropriate NSF recognized by the ISO, the NSF structure itself does not recognize all the constituents of a particular sport, and thus imposed decisions usually do not meet the actual needs of interested parties. There are continuous misuse of autonomy in imposing restrictive (often discriminatory) obligations, resulting in withholding of rights, especially in terms of representation and the decision-making process. That said, the policy interventions reflects omnipresent political influence, focusing on regulatory framework, rather than implementation processes (Begović 2020). Contemporary developments of sport law has moved from an organizational to a state-centric model, whereas sports autonomy is limited due to the interventionist institutional arrangements including a dominant orientation on public funding.

\section{Competing Interests}

The author has no competing interests to declare.

\section{Author Information}

Marko Begović holds a PhD from German Sport University, MA in Olympic Studies and Spec. Sci in Foreign Policy and Diplomacy and BA in Sports Management. Begović is an Associate Professor at the Faculty of Sport in Belgrade. Dr. Begović's research interests include sports policy and politics, management and history.

\section{References}

Begović, M. 2020. The Development of Sport Policy in Montenegro. International Journal of Sport Policy and Politics, 12(2): 321-330. DOI: https://doi.org/10.1080/19406940.2020.1719186

Begović, M, Bardocz-Bencsik, M, Oglesby, CA and Dóczi, T. 2020. The Impact of Political Pressures on Sport and Athletes in Montenegro. Sport in Society, 24(7): 1200-1216. DOI: https://doi.org/10.1080/17430437.2020.1738393

Bergsgard, NA, Houlihan, B, Mangset, P, Nodland, SI and Rommetvedt, H. 2007. Sport Policy: A Comparative Analysis of Stability and Change. Oxford: Butterworth-Heinemann.

Bogišić, V. 1898. Opšti imovinski zakonik za Knjaževinu Crnu Goru [The General Property Code for the Principality of Montenegro]. Cetinje, Montenegro. Available at: https://www.harmonius.org/sr/pravni-izvori/jugoistocna-evropa/ privatno-pravo/crna-gora/Opsti_imovinski_zakonik_CG.pdf. Last accessed October 22, 2020

Directive 2006/123/EC. Directive on Services in the Internal Market. European Parliament, Council of the European Union. Available at: https://eur-lex.europa.eu/legal-content/EN/TXT/?uri=celex\%3A32006L0123. Last accessed October 23, 2020.

Đorđević, J. 1975. Ustavno Pravo. Beograd: Savremena Administracija.

Government of Montenegro. 2008a. Law on Obligations. Official Gazette No. 47/08.

Government of Montenegro. 2008b. Law on Ratification of International Convention against Doping in Sport. Official Gazette No. 6/08.

Government of Montenegro. 2012. Law on NGO. Official Gazette No 66/12.

Government of Montenegro. 2017a. Law on Prevention of Spectator Violence and Misbehaviour at Sport Events. Official Gazette No. 51/2017.

Government of Montenegro. 2017b. Law on Public Ski Slopes. Official Gazette No. 044/17.

Government of Montenegro. 2017c. Rules of Procedure of Government. Official Gazette No. 3/12; 31/15; $48 / 17$.

Government of Montenegro. 2018a. Decree for Compensation Amount and Premiums for Achieving Sporting Results. Official Gazette No 057/18.

Government of Montenegro. 2018b. Decree on Government. Official Gazette No. 80/08; 14/17; 28/18.

Government of Montenegro. 2018c. Law on Sport. Official Gazette No. 044/18.

Government of Montenegro. 2018d. Law on State Administration. Official Gazette No. 013/18.

Government of Montenegro. 2019a. Decree on Organization and Operation of the State Authorities. Official Gazette No. 087/18; 002/19.

Government of Montenegro. 2019b. Law on Budget and Fiscal Responsibility. Official Gazette No. 74/2019.

Lukić, R. 1957. Teorija Države i Prava II. Beograd: BIGZ.

Organisation for Economic Co-operation and Development. 2003. OECD Economic Surveys: Federal Republic of Yugoslavia 2002. Paris: OECD Publishing. Last accessed March 10, 2020. 
Parliament of Montenegro. 2007. Constitution of Montenegro. Available at: http://www.skupstina.me/index.php/ me/ustav-crne-gore. Last accessed October 13, 2020. DOI: https://doi.org/10.1787/eco_surveys-srb-2002-en

Parliament of the Socialist Republic of Montenegro. 1957. State Archive of Montenegro 1957 Decree to establish the Republic Commission for Physical Education. Official Gazette People's Republic of Montenegro, no. 18/57.

Parliament of the Socialist Republic of Montenegro. 1965. State Archive of Montenegro 1965 Law on Republic Administration. Official Gazette People's Republic of Montenegro, no. 9/65.

Petrić, S. 2006. Odgovornost za Materijalne Nedostatke Stvari Prema Novom Zakonu o Obveznim Odnosima. Zbornik Pravnog fakulteta Sveučilišta u. Rijeci, 27(1): 87-128.

Radunović, R. 1980. Pojava i Razvoj Modernog Sporta u Crnoj Gori do 1914 [The Emergence and Development of Modern Sport in Montenegro Until 1914]. Fizička Kultura, 1(1980): 109-116.

Radunović, R. 1983. Neka Iskustva iz Cetvorogodišnjeg Rada i Ostvarivanja Delegatskog Sistema u RSIZ [Some Experiences from the 4 Year Work and Application of Delegate System in the Republic Self-Management Communities of Interest]. Fizička Kultura, 3(1983): 23-30.

State Archive of the Socialist Federal Republic of Yugoslavia (SFRY). 1932. Law on Mandatory Physical Education. Official Gazette Kingdom of Yugoslavia, no. 76/1932.

Vujošević, V. 1983. Pregled rada Komisije za Fizičku Kulturu Crne Gore za Period 1955-1956 [Review of the Work of the Commission for Physical Culture of Montenegro]. Fizička Kultura, 2(1983): 123-129.

Yugoslav Association for Physical Culture. 1975. Social Agreement on the Athletes. Belgrade: SFKJ Off. Gazette 3-4. Republic Self-Managing Communities of Interest fund (Box 1). Cetinje: State Archives of Montenegro.

How to cite this article: Begović, M. 2021. Sports Law in Montenegro: Origins and Contemporary Development. Entertainment and Sports Law Journal, 19: 1, pp.1-8. DOl: https://doi.org/10.16997/eslj.912

Submitted: 02 November 2020 Accepted: 29 May 2021 Published: 26 July 2021

Copyright: ๑ 2021 The Author(s). This is an open-access article distributed under the terms of the Creative Commons Attribution 4.0 International License (CC-BY 4.0), which permits unrestricted use, distribution, and reproduction in any medium, provided the original author and source are credited. See http://creativecommons.org/licenses/by/4.0/. 